\title{
Article \\ Comparative Research of Thermochemical Conversion Properties of Coarse-Energy Crops
}

\author{
Živilè Černiauskienè ${ }^{1, *}$, Algirdas Jonas Raila ${ }^{1}$, Egidijus Zvicevičius ${ }^{1}$, Vita Tilvikienè ${ }^{2}$ (D) \\ and Zofija Jankauskiené ${ }^{2}$ \\ 1 Department of Mechanical, Energy and Biotechnology Engineering, Vytautas Magnus University, \\ Studentu str. 15, 53362 Akademija, Kaunas Distr., Lithuania; algirdas.raila@vdu.lt (A.J.R.); \\ egidijus.zvicevicius@vdu.lt (E.Z.) \\ 2 Lithuanian Research Centre for Agriculture and Forestry, Instituto al. 1, \\ 58344 Akademija, Kèdainiai Distr., Lithuania; vita.tilvikiene@lammc.lt (V.T.); \\ sofija.jankauskiene@lammc.lt (Z.J.) \\ * Correspondence: zivile.cerniauskiene@vdu.lt
}

Citation: Černiauskienè, Ž.; Raila, A.J.; Zvicevičius, E.; Tilvikienė, V.; Jankauskienè, Z. Comparative Research of Thermochemical Conversion Properties of Coarse-Energy Crops. Energies 2021, 14, 6380. https://doi.org/10.3390/ en14196380

Academic Editor: Ulugbek Azimov

Received: 19 August 2021

Accepted: 26 September 2021

Published: 6 October 2021

Publisher's Note: MDPI stays neutral with regard to jurisdictional claims in published maps and institutional affiliations.

Copyright: (c) 2021 by the authors. Licensee MDPI, Basel, Switzerland. This article is an open access article distributed under the terms and conditions of the Creative Commons Attribution (CC BY) license (https:/ / creativecommons.org/licenses/by/ $4.0 /)$.

\begin{abstract}
In the world, as in Lithuania, there is a costant search for new crops suitable for energy conversion. The coarse-energy crops and their biomass studied for this paper were assessed in a comprehensive manner, i.e., not only their calorific value and ash content but also their ash melting properties and pollutants emitted during the thermochemical conversion. The calorific value of energy crops varies from $17.92 \pm 0.32$ to $18.50 \pm 0.66 \mathrm{MJ} \mathrm{kg}^{-1}$ and decreases in the following order: A. dubia $>$ M. giganteus $>$ C. sativa. Ash content varies from $1.51 \pm 0.03$ to $3.36 \pm 0.23 \%$ and decreases in the following order: C. sativa $>A$. dubia $>$. giganteus. The lowest primary ash deformation $\left(648 \pm 8^{\circ} \mathrm{C}\right)$ was recorded for $C$. sativa. Taking into account the specificity of our research and the changes in biomass ash content due to mineral nitrogen fertilization, it has been found that that higher levels of nitrogen fertilizers in the combustion products reduce $\mathrm{CO}$ and increase the total $\mathrm{CO}_{2}$ content of the combustion product. Significant changes in fertilization were usually $170 \mathrm{~kg} \mathrm{ha}^{-1}$ for A. dubia and $90 \mathrm{~kg} \mathrm{ha}^{-1}$ for M. giganteus. In summary, A. dubia, M. giganteus and C. sativa biomass should be used for thermochemical conversion.
\end{abstract}

Keywords: Artemisia dubia Wall.; Miscanthus $\times$ giganteus; Cannabis sativa L.; biomass; thermal properties; emissions; mineral fertilizers

\section{Introduction}

In the world, as in Lithuania, new non-traditional energy crops suitable and efficient for energy conversion are constantly being researched and sought. There are certain requirements for such crops. It is essential that they would be undemanding for soil quality, applied cultivation and harvesting technologies. They must also be distinguished by high yields, but not contribute to increasing greenhouse gas (GHG) emissions as well as have minimal impact on the environment.

In northern European countries, annual energy crops are popular because of their more accessible inclusion in crop rotation, their cost is lower, and farmers have more experience in growing them [1,2]. However, non-food perennials crops are valued for their conservation of biodiversity and their positive impact on the net energy balance because they can grow in the same place for ten years or more, and their biomass is harvested annually [2-4]. Such crops can be a viable raw material for the production of solid biofuels. Therefore, much attention is paid to the group of coarse-energy crops, including perennials (mugwort and namely Miscanthus) and annuals (fibrous hemp) crops.

However, with regard to the soil condition, the cultivation technologies used and, in particular, the climatic conditions, the productivity of energy crops grown around the world varies. In the cool climates zone, yields of Miscanthus can reach $18 \mathrm{tha}^{-1}$ [3-5], 
fibrous hemp, depending on their variety, from 8 to $15 \mathrm{t} \mathrm{ha}^{-1}$ [6-8]. Mugworts are popular in medicine; therefore, little research has been carried out on energy properties. However, research conducted in Lithuania has shown that under optimal growth conditions, biomass productivity can exceed $20 \mathrm{tha}^{-1}$ of dry weight $[4,9]$.

In order to use the biomass of such coarse-energy crops for thermochemical conversion, it is essential to know their calorific value, ash content and ash melting temperatures. Without knowing the properties of the biomass used and with ash content remaining high, the later formation of non-combustible impurities in the biomass layer and when they began to melt, this has an influence on unwanted slag process in the combustion chamber and negatively affects the operation of the boiler. Biomass ash has a low ash melting point compared to wood, i.e., deformation temperatures (DT) are mainly 750-1000 ${ }^{\circ} \mathrm{C}$ [10-12]. At low ash melting temperatures where there is a need to burn a biofuel of energy crops with such properties, controlling the combustion process properly is essential. However, it must be considered that the emissions and the quantity generated during thermochemical conversion must be assessed. This is very important when assessing the environmental impact of coarse-energy crops, i.e., emissions during thermochemical conversion from the burning. Typically, scientists research and evaluate emissions in the airflow [13-16]. The coarse-energy crops and their biomass studied for this article were assessed in a comprehensive manner, i.e., not only their calorific value and ash content but also their ash melting properties and pollutants emitted during the thermochemical conversion. This study intended to evaluate emissions during thermochemical conversion from the burning from $1 \mathrm{~kg}$ of crop biomass.

In order to improve the yield of energy crops, additional mineral fertilizers are often used during cultivation $[2,4,8,17,18]$. In this case, it is equally important to assess the effect of mineral fertilizers on the thermal properties of crop biomass and determine whether their use has an influence on biomass. Perhaps, it is simply inappropriate to use an agrotechnical operation which requires additional energy consumption.

The properties of $A$. dubia and $M$. giganteus were studied in terms of their mineral nitrogen fertilization, as their main purpose is biomass thermochemical conversion. However, Cannabis sativa L. areas have recently become very popular and are being rapidly cultivated, mainly for cereals and fiber. Additionally, C. sativa is a valuable raw material in the textile and paper industry, and it should be used for energy purposes when it does not meet the quality requirements for the primary uses or is in surplus. Agro technical fertilization with mineral nitrogen is therefore completely irrelevant for them. The biomass of C. sativa is analyzed for comparison in terms of thermochemical conversion, i.e., as a promising crop. This is because it generates large quantities of waste after its direct use, which can also be used for bioenergy purposes.

The aim of the study is to determine the thermal properties and emissions during thermochemical conversion of coarse-energy crops (Artemisia dubia Wall., Miscanthus $\times$ giganteus and Cannabis sativa L.) and to evaluate the expediency of using mineral nitrogen fertilization technology for perennial crops.

\section{Materials and Methods}

\subsection{Object of Research}

Artemisia dubia Wall. (mugwort), Miscanthus $\times$ giganteus (namely Miscanthus) and Cannabis sativa L. (fiber hemp) were grown (Figure 1) in a plantation set up at an experimental basis of Lithuanian Research Centre for Agriculture and Forestry Institute of Agriculture, and the research work on fuel preparation and thermal conversion was carried out at the Laboratory of Biomass Processes, Logistics and Solid Fuel Processing of the Faculty of Agricultural Engineering, Vytautas Magnus University.

A. dubia and M. giganteus were grown using three fertilization technologies (not fertilized, fertilized with mineral nitrogen fertilizers 90 and $170 \mathrm{~kg} \mathrm{ha}^{-1}$ ). C. sativa crops were not fertilized during growth. The experiment was set up in a randomized block 
design with a size of $7 \mathrm{~m}^{2}$ and three repetitions, i.e., $3 \times 7 \mathrm{~m}^{2}$. The field experiments were carried out over a three-year period.

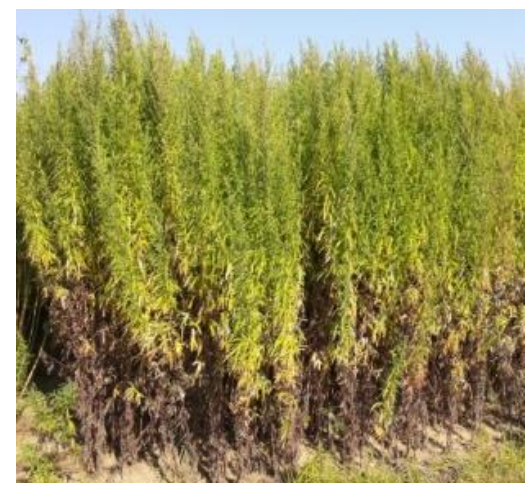

(a)

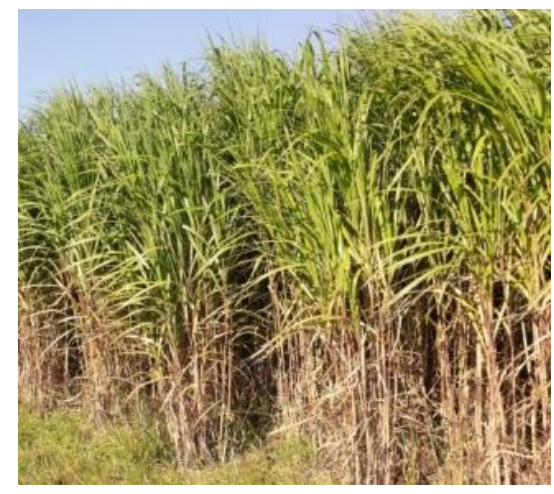

(b)

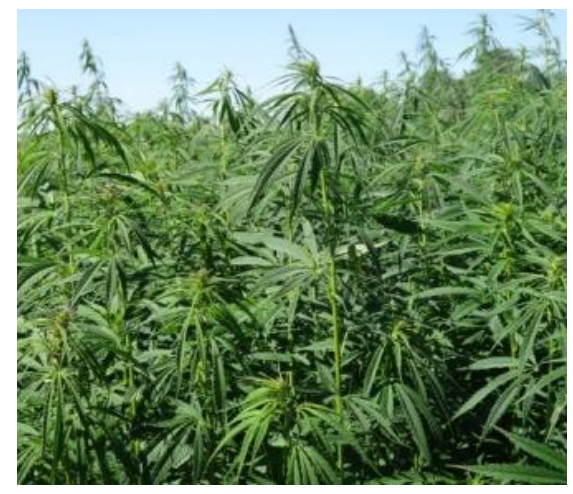

(c)

Figure 1. Coarse-energy crops: Artemisia dubia Wall. (a), Miscanthus $\times$ giganteus (b), Cannabis sativa L. (c).

\subsection{Biomass Preparation}

Biomass of energy crops was shredded with a drum shredder ALKO Silent Power 4000 (AL-KO Kober AG, Kötz, Germany) till $23.2 \pm 2.9 \mathrm{~mm}$ length fractions and it's humidity was determined by drying in Memmert UPF 700 (Memmert GmbH, Büchenbach, Germany) at $105 \pm 2{ }^{\circ} \mathrm{C}$ to constant weight. Biomass was completed to grind with a mill Retsch SM300 (Retsch GmbH, Haan, Germany) at $1500 \mathrm{rpm}$. min $^{-1}$ using a $1 \mathrm{~mm}$ sieve.

\subsection{Determination of Calorific Value}

The calorific value of Artemisia dubia Wall., Miscanthus $\times$ giganteus and Cannabis sativa L. was determined using a calorimeter IKA C2000 (IKA ${ }^{\circledR}$-Werke GmbH \& Co. KG, Staufen im Breisgau, Germany) according to the methodology specified in standard EN 14918. Previously, the raw material was compressed into approximately $1 \mathrm{~g}$ pellets with a hand press IKA C21 (IKA ${ }^{\circledR}$-Werke GmbH \& Co. KG, Staufen im Breisgau, Germany), and its moisture content was determined.

\subsection{Determination of Ash Content}

Ash content was determined according to the methodology specified in standard EN 14775. One gram of sample was taken from a well-mixed total biomass sample, placed in a preheated and weighted with scales KERN ABJ (Kern \& Sonh GmbH, Balingen, Germany) balance to the nearest $0.1 \mathrm{mg}$. The sample was spread as a layer of uniform thickness on the plate bottom. The dish with the sample was weighed and placed in a cold heating oven CZYLOK (CZYLOK Company, Jastrzębie-Zdrój, Poland). In parallel, the moisture in the test biomass sample was determined according to the methodology specified in standard EN 14774-3.

\subsection{Determination of Ash Melting Characteristics}

The ash obtained using heating oven CZYLOK in accordance with the methodology specified in standard EN 14775 was further used to determine its melting characteristics. Therefore, they were moistened with distilled water, preparing a mass of wet consistency from which roll-shaped samples $4 \mathrm{~mm}$ in diameter and $5 \mathrm{~mm}$ high are formed using a hand press. Then, they were placed in pairs on ceramic plates and put in a heating furnace Carbolite Caf Digital (Carbolite Gero Ltd., Hope S33 6RB, UK). The furnace was closed, and the surveillance chamber with the light source was switched on. Having adjusted the gas supply and created an oxidizing environment, the samples were heated in the oven to the ash discharge temperature, and their images were periodically recorded on a computer every $1{ }^{\circ} \mathrm{C}$. A particular Carbolite computer program was used to analyze the photographs saved during the study and to record the temperatures at which changes in 
the state of the ash samples occur. Ash melting temperatures were determined according to the methodology specified in standard CEN/TS 15370-1. All four ash melting phase temperatures were determined: DT, deformation temperature; $\mathrm{ST}$, softening temperature; $\mathrm{HT}$, hemispherical temperature; FT, flow temperature.

\subsection{Determination of Emissions during Thermochemical Conversion}

The process of thermal conversion of A. dubia, M. giganteus and Cannabis was investigated in experimental studies. During the process, the kinematics and amounts of carbon dioxide $\left(\mathrm{CO}_{2}\right)$, carbon monoxide $(\mathrm{CO})$, total nitrogen oxides $\left(\mathrm{NO}_{\mathrm{x}}\right)$ and nitrogen monoxide $(\mathrm{NO})$, sulfur dioxide $\left(\mathrm{SO}_{2}\right)$ formation were recorded with a portable emission analyzer Testo 350 (Testo SE \& Co. KGaA, West Chester, PA, USA).

A specially designed biomass thermal conversion and smoke emission test stand, the schematic diagram of which is shown in Figure 2, was used to estimate the emissions of combustion products from the thermal conversion of biomass.

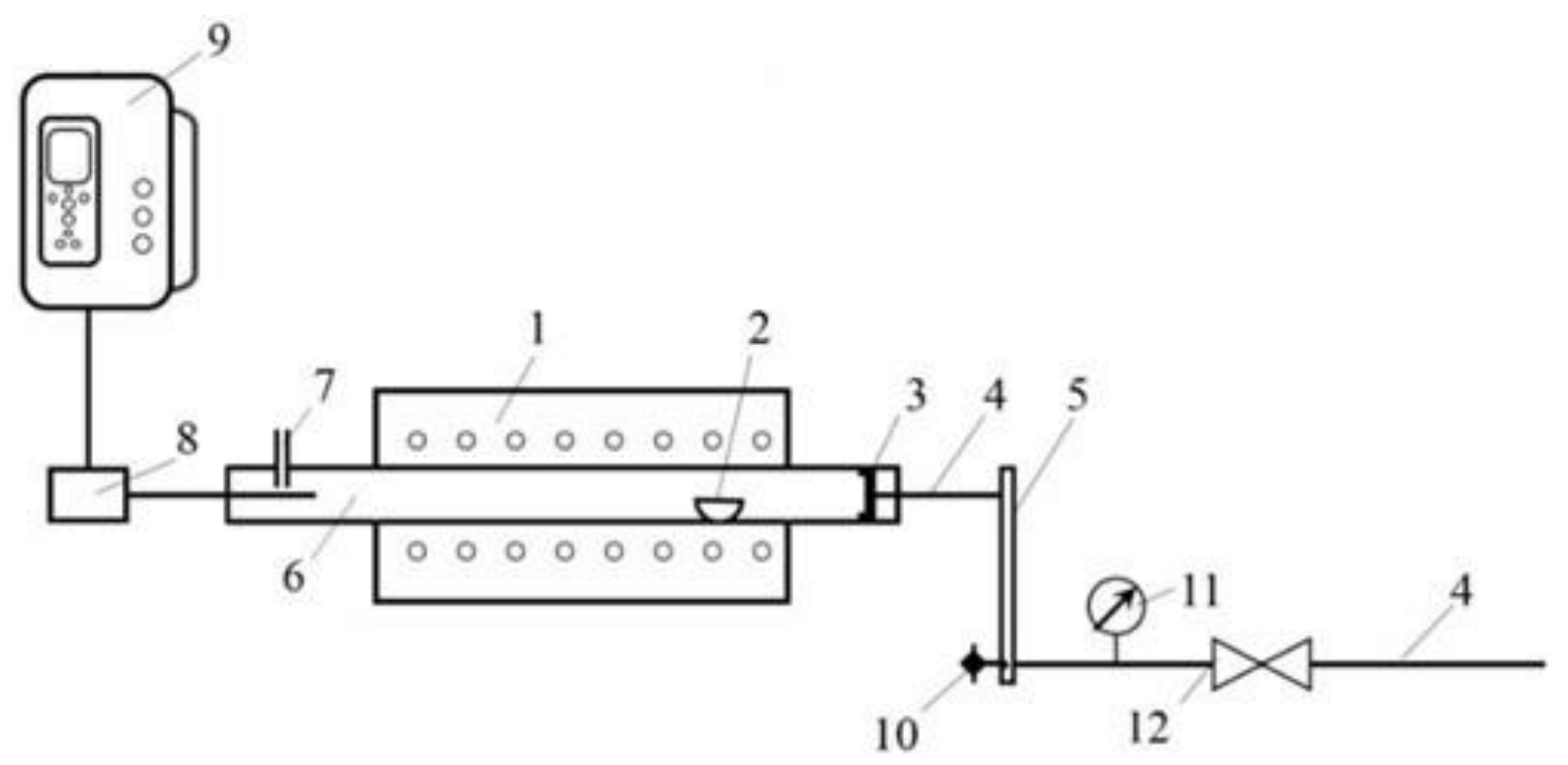

Figure 2. Schematic diagram of biomass thermal conversion and smoke emission test bench: 1, tubular heating furnace; 2 , crucible with a sample of combusted biomass; 3 , sealing plug; 4, air supply hose; 5 , air flow meter; 6 , combustion chamber; 7, chimney; 8 , smoke extractor; 9, smoke analyzer; 10, air flow control valve; 11, manometer; 12, valve.

A. dubia, M. giganteus and C. sativa were shredded with a Retsch SM300 to a particle size of $1 \mathrm{~mm}$. A sample of about $1 \mathrm{~g}$ of biomass was then weighed to the nearest $0.1 \mathrm{mg}$ on a KERN ABJ balance. A smoke emission test program was run on the smoke analyzer Testo 350 and the smoke pump began to pump air from the combustion chamber in front of the chimney. The crucible with the prepared biomass sample is then placed in the combustion chamber of a tubular heating furnace Nabertherm RS 120/500/11 (Nabertherm GmbH, Lilienthal, Germany) heated to $900{ }^{\circ} \mathrm{C}$. At the beginning of the combustion process of the prepared biomass, the composition of the emitted gases and their amount were recorded and saved in the smoke analyzer. Measurement results were recorded every $1 \mathrm{~s}$. At the end of the thermal conversion process, the capture of the evolved gases and their amount was stopped and the crucible with biomass ash was removed from the combustion chamber of the tubular heating furnace. The experiments were performed in 8 replicates.

After analyzing the obtained research results, the combustion of combustion products formed per kilogram of biomass was calculated according to the equation [19-21]:

$$
V_{d p}=V_{R_{2}}+V_{N_{2}}+(\alpha-1) \cdot V_{O}^{t}+V_{H_{2} O},
$$

where: 
$V_{d p}$, theoretical volume of combustion products from $1 \mathrm{~kg}$ of biomass $\left[\mathrm{m}^{3}\right]$;

$V_{\mathrm{RO}_{2}}$, volume of triatomic gases $\left(\mathrm{CO}_{2}\right.$ and $\left.\mathrm{SO}_{2}\right)$ in the smoke $\left[\mathrm{m}^{3}\right]$;

$V_{\mathrm{N}_{2}}$, the volume of nitrogen gas in the smoke $\left[\mathrm{m}^{3}\right]$;

$\alpha$, excess air ratio;

$V_{\mathrm{O}^{\prime}}^{t}$, theoretical amount of air required to burn $1 \mathrm{~kg}$ of biomass $\left[\mathrm{m}^{3}\right]$;

$V_{\mathrm{H}_{2} \mathrm{O}}$, the volume of water vapor occupied by the smoke $\left[\mathrm{m}^{3}\right]$.

The volume of triatomic gas in the smoke was determined by the equation [21]:

$$
V_{R O_{2}}=0.01866 \cdot\left(C^{n}+0.375 \cdot S_{l}^{n}\right),
$$

where:

$C^{n}$, carbon content of the researched biomass [\%];

$S_{l}^{n}$, sulfur content of the researched biomass [\%].

The volume of nitrogen gas in the smoke was determined according to the equation:

$$
V_{N_{2}}=0.79 \cdot V_{\text {oro }}+0.008 \cdot N^{n},
$$

where:

$V_{\text {oro }}$, the amount of air required $\left[\mathrm{m}^{3} \mathrm{~kg}^{-1}\right.$ biomass];

$N^{n}$, nitrogen content of the researched biomass [\%].

The excess air coefficient was determined by the equation:

$$
\alpha=\frac{V_{o r o}^{f}}{V_{o r o}^{o}},
$$

where:

$V_{\text {oro }}^{f}$, the actual amount of air supplied to the furnace $\left[\mathrm{m}^{3} \mathrm{~h}^{-1}\right]$;

$V_{\text {oro }}^{o}$, theoretically required amount of air $\left[\mathrm{m}^{3} \mathrm{~kg}^{-1}\right.$ biomass].

The volume of water vapor in the smoke is determined by the equation [19-21]:

$$
V_{H_{2} \mathrm{O}}=0.1111 \cdot H^{n}+0.0124 \cdot W^{n}+0.0161 \cdot \alpha \cdot V_{\text {oro }}^{o},
$$

where:

$H^{n}$, hydrogen content of the biomass under researched [\%];

$W^{n}$, moisture content of the researched biomass [\%].

Having estimated the volume of combustion products formed during the thermal conversion, the emissions from the burning of $1 \mathrm{~kg}$ of $A$. dubia, M. giganteus and C. sativa were determined.

\subsection{Statistical Analysis}

The results of the tests were determined in at least five replicates and data were presented as mean values with confidence levels. The least significant difference (LSD Post Hoc test) was calculated using Statistica 10.0 software at 95\% confidence level.

\section{Results}

The calorific value of perennial (Artemisia dubia Wall. and Miscanthus $\times$ giganteus) and annual (Cannabis sativa $\mathrm{L}$.) energy crops determined by experimental studies is presented in Figure 3. It was observed that the calorific value of energy crops varied from $17.92 \pm 0.32$ to $18.50 \pm 0.66 \mathrm{MJ} \mathrm{kg}^{-1}$, but no reliable difference between crop calorific values was found. It decreases in this order:

A. dubia $>$ M. giganteus $>$ C. sativa 


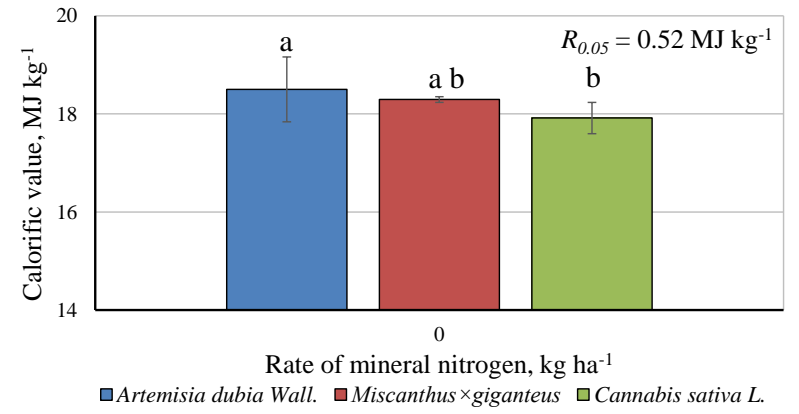

(a)

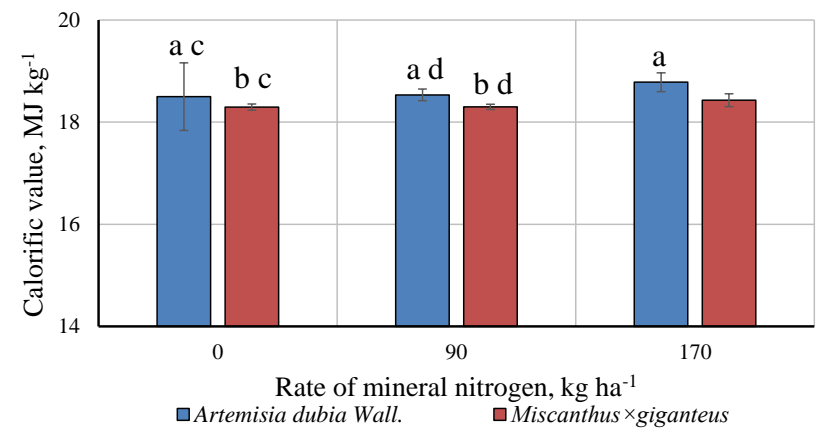

(b)

Figure 3. The dependence of the calorific value of above-ground crops of Artemisia dubia Wall., Miscanthus $\times$ giganteus and Cannabis sativa L. not fertilized (a), on mineral nitrogen fertilization (b) $\left(R_{0.05}(\right.$ A.dubia $)=0.55 \mathrm{MJ} \mathrm{kg}^{-1}$, $R_{0.05}(M$. giganteus $)=0.12 \mathrm{MJ} \mathrm{kg}^{-1}, R_{0.05}($ A. dubia $\times M$. giganteus $)=0.12 \mathrm{MJ} \mathrm{kg}^{-1} . \mathrm{a}, \mathrm{b}, \mathrm{c}$, $\mathrm{d}$, there are no statistically significant differences $(p<0.05)$ between the columns marked with the same letter, as assessed using the least significant difference.

When analyzing the effect of mineral nitrogen fertilization on perennial crops, it was noted that $A$. dubia biomass was larger; i.e., by fertilizing them with $170 \mathrm{~kg} \mathrm{ha}^{-1}$, the average calorific value can be increased to $0.28 \mathrm{MJ} \mathrm{kg}^{-1}$. However, no reliable differences in the determined calorific values were observed when fertilizing A. dubia and M. giganteus biomass with mineral nitrogen.

The ash yield of coarse-energy crops varied from $1.51 \pm 0.03$ to $3.36 \pm 0.23 \%$; i.e., the ash content of $C$. sativa was 1.25 and 2.22 times higher than that of $A$. dubia and $M$. giganteus, respectively (Figure 4). The ash content of coarse-energy crops decreases in the following order:

$$
\text { C. sativa }>\text { A. dubia }>\text { M. giganteus }
$$

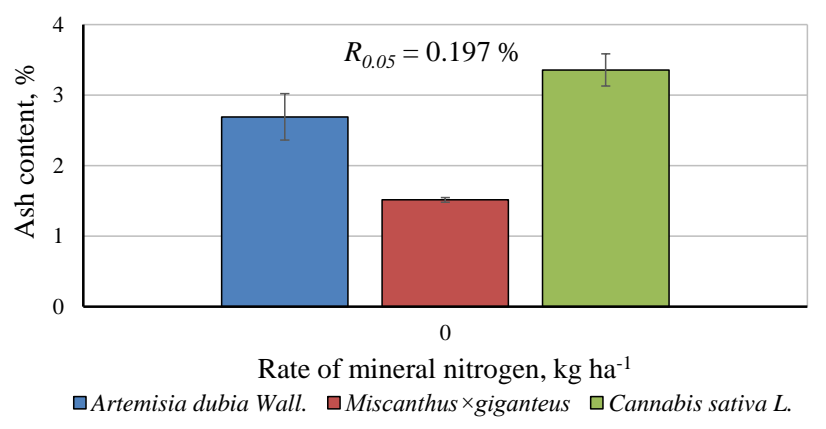

(a)

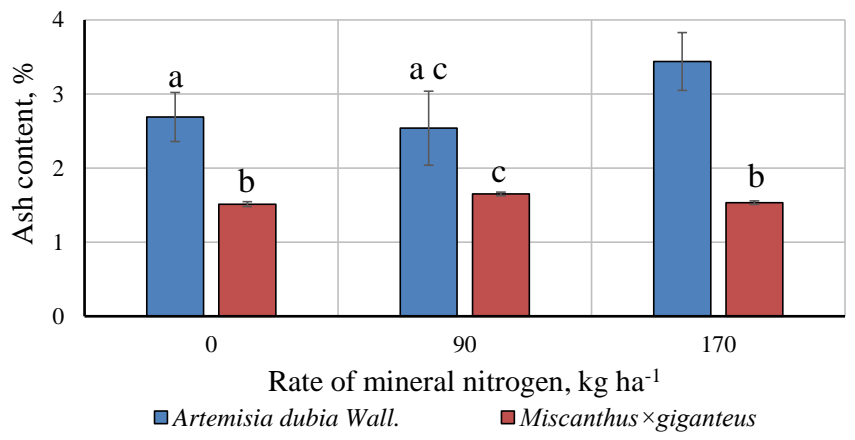

(b)

Figure 4. The dependence of ash content of above-ground crops parts of Artemisia dubia Wall., Miscanthus $\times$ giganteus and Cannabis sativa L. not fertilized (a), on mineral nitrogen fertilization $(\mathbf{b})\left(R_{0.05}(\right.$ A. dubia $)=0.152 \%, R_{0.05}(M$. giganteus $)=0.043 \%$, $R_{0.05}($ A. dubia $\times$ M. giganteus $)=0.089 \%$. a, b, c, there are no statistically significant differences $(p<0.05)$ between the columns marked with the same letter, as assessed using the least significant difference.

Fertilization of perennial crop biomass with mineral nitrogen has different effects. Fertilization of $170 \mathrm{~kg} \mathrm{ha}^{-1}$ showed a reliable increase in ash content of $0.75 \%$ on average, and fertilization of $90 \mathrm{~kg} \mathrm{ha}^{-1}$ showed a lower average ash yield; however, this difference was not statistically significant. In the case of $M$. giganteus, a reliable difference of $0.14 \%$ on average was observed when fertilizing their biomass with $90 \mathrm{~kg} \mathrm{ha}^{-1}$ of mineral nitrogen, nevertheless, the value of ash content increased. When fertilizing M. giganteus with $170 \mathrm{~kg} \mathrm{ha}^{-1}$, the ash content was determined within the range of other errors compared to the unfertilized variant.

Analysis of the primary deformation temperature of A. dubia, M. giganteus and C. sativa (Figure 5) revealed that it was most characteristic of fibrous hemp ash $\left(648 \pm 8{ }^{\circ} \mathrm{C}\right)$; 
the figure was 1.10 times and 1.25 times lower than for A. dubia and M. giganteus ash, respectively. It decreases in the following order:

\section{M. giganteus $>$ A. dubia $>$ C. sativa}

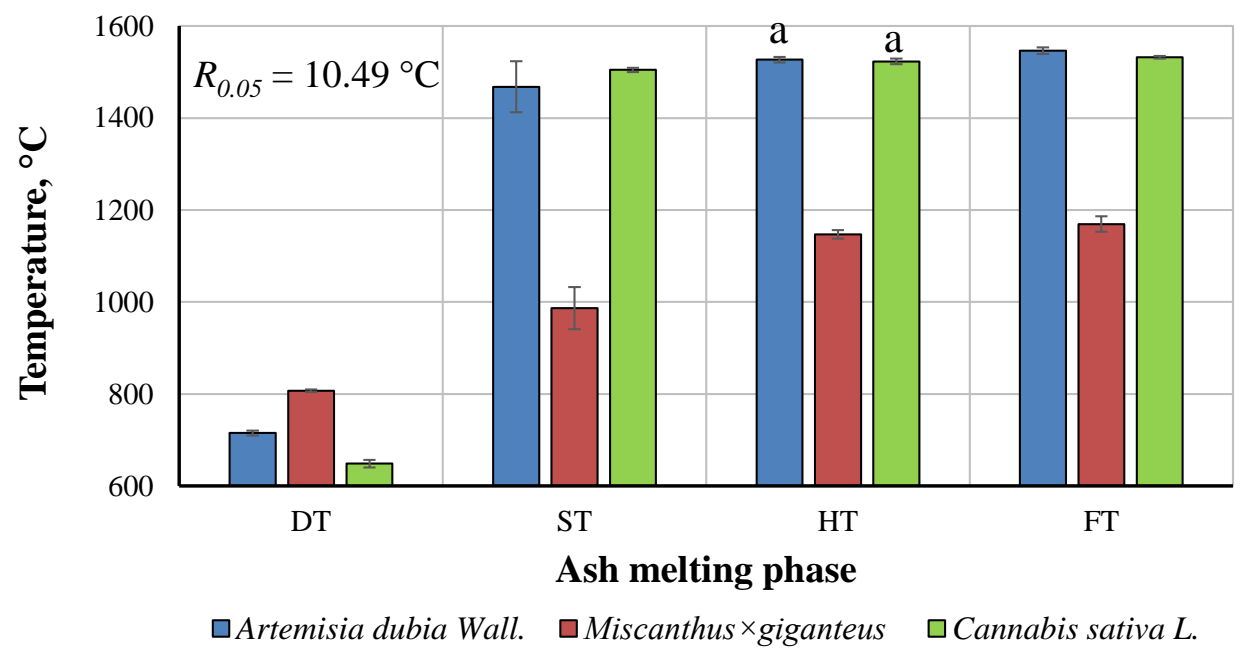

Figure 5. Ash melting temperature of Artemisia dubia Wall., Miscanthus $\times$ giganteus and Cannabis sativa L. not fertilized: DT, deformation temperature; ST, softening temperature; HT, hemispherical temperature; FT, flow temperature; a, there are no statistically significant differences $(p<0.05)$ between the columns marked with the same letter, as assessed using the least significant difference.

However, other ash melting characteristics of $M$. giganteus ash have been recorded as being lower than other crops. Softening temperature decreases in the following order:

$$
\text { C. sativa }>\text { A. dubia }>\text { M. giganteus }
$$

Hemispherical and flow temperatures decrease in the following order:

$$
\text { A. dubia }>\text { C. sativa }>\text { M. giganteus }
$$

The melting characteristics of $M$. giganteus ash ST, HT and FT were recorded at $986 \pm 46^{\circ} \mathrm{C}, 1147 \pm 9^{\circ} \mathrm{C}$ and $1169 \pm 17^{\circ} \mathrm{C}$, respectively. This is 1.49 and 1.53 times in the ST phase, 1.33 and 1.31 times in HT, and 1.32 and 1.31 times in FT than in the case of A. dubia and C. sativa, respectively.

Figure 6 shows the melting temperature characteristics of A. dubia ash (a) and M. giganteus (b) ash, taking into account non-fertilization and fertilization of crops with mineral nitrogen 90 and $170 \mathrm{~kg} \mathrm{ha}^{-1}$ rate. The DT characteristic of not fertilized $A$. dubia ash was recorded at $715 \pm 5{ }^{\circ} \mathrm{C}$, i.e., 1.13 times lower than $M$. giganteus. Fertilization with mineral nitrogen had a more significant effect on $M$. giganteus: fertilization with a $90 \mathrm{~kg} \mathrm{ha}^{-1}$ rate may delay the DT characteristics by $88^{\circ} \mathrm{C}$, or $72{ }^{\circ} \mathrm{C}$ for the $170 \mathrm{~kg} \mathrm{ha}^{-1}$ rate. In the case of $A$. dubia, fertilization with the highest mineral nitrogen rate delays the DT characteristic only by $10{ }^{\circ} \mathrm{C}$, compared to the unfertilized variant.

The ST, HT and FT characteristics of M.giganteus have been achieved previously, i.e., $1.49,1.33$ and 1.32 times earlier, respectively than $A$. dubia ash when analyzing unfertilized variants. The most considerable influence on fertilization was found in the delay of ST characteristic, when M.giganteus were fertilized with $170 \mathrm{~kg} \mathrm{ha}^{-1}\left(190{ }^{\circ} \mathrm{C}\right)$, and $90 \mathrm{~kg} \mathrm{ha}^{-1}$ $\left(182{ }^{\circ} \mathrm{C}\right)$, in comparison with the not fertilized variant. In the case of $A$. dubia ash with $170 \mathrm{~kg} \mathrm{ha}^{-1}\left(23^{\circ} \mathrm{C}\right)$ and with $90 \mathrm{~kg} \mathrm{ha}^{-1}$ it varies within the range of errors, compared with the not fertilized variant. Analyzing the effect of fertilization of A. dubia in the delay of HT and FT characteristics, it was observed that HT had no effect, and FT was delayed only by $10^{\circ} \mathrm{C}$, where fertilization was applied with the highest rate of mineral nitrogen. In 
the case of M.giganteus ash, HT is delayed by $37^{\circ} \mathrm{C}$ (using $90 \mathrm{~kg} \mathrm{ha}{ }^{-1}$ ) and FT by $30^{\circ} \mathrm{C}$ (using $170 \mathrm{~kg} \mathrm{ha}^{-1}$ ).

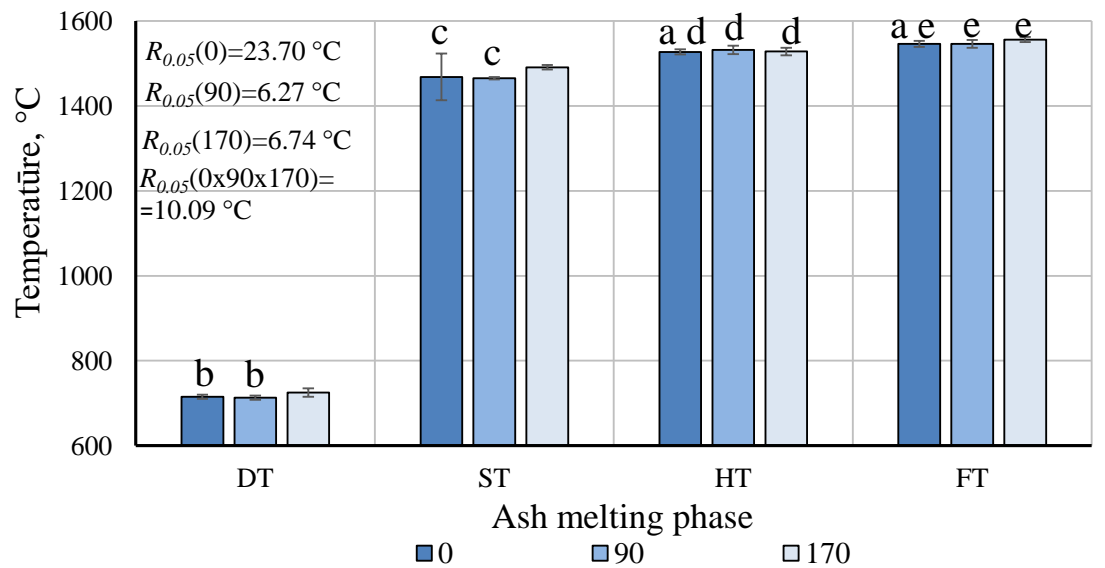

(a)

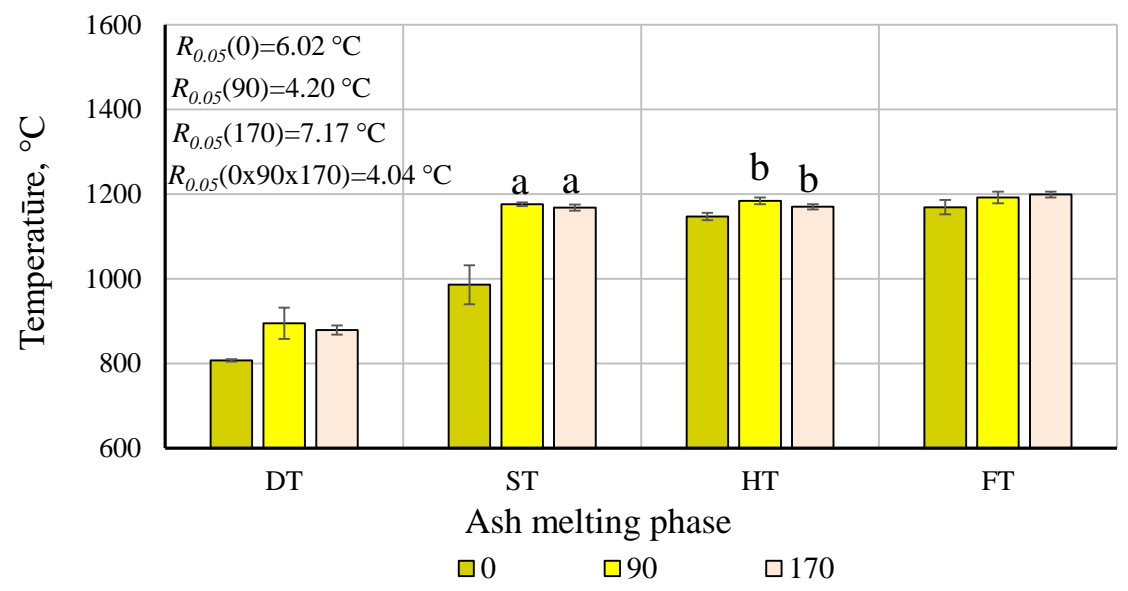

(b)

Figure 6. Ash melting temperature of Artemisia dubia Wall. (a), Miscanthus $\times$ giganteus (b) when they were not fertilized, fertilized with mineral nitrogen fertilizers 90 and $170 \mathrm{~kg} \mathrm{ha}^{-1}$ : DT, deformation temperature; ST softening temperature; HT, hemispherical temperature; FT, flow temperature; a, b, c, $\mathrm{d}$, e, there are no statistically significant differences $(p<0.05)$ between the columns marked with the same letter, as assessed using the least significant difference.

When estimating the composition of emissions during the thermochemical conversion, it was estimated that the combustion of $1 \mathrm{~kg}$ of biomass produces an average of $85.7 \pm 0.119 \mathrm{~m}^{3}$ of combustion products, when the excess air ratio varies from 9.93 to 10.78 . Carbon dioxide accounted for the largest share of combustion products.

When having compared the $\mathrm{CO}_{2}$ emissions of perennial energy crops, it was monitored that $\mathrm{CO}_{2}$ emissions from $170 \mathrm{~kg} \mathrm{ha}^{-1}, 90 \mathrm{~kg} \mathrm{ha}^{-1}$ and without fertilization were $1.01,1.09$ and 1.10 times lower, respectively, than for M. giganteus (Figure 7). The average $\mathrm{CO}_{2}$ emissions of annual C. sativa were $1892.81 \pm 15.04 \mathrm{~g} \mathrm{~kg}^{-1} \mathrm{DM}$, i.e., 1.01 times increased than in A. dubia and 1.08 times less than in M. giganteus. The average $\mathrm{CO}_{2}$ emissions decrease in the following order: 


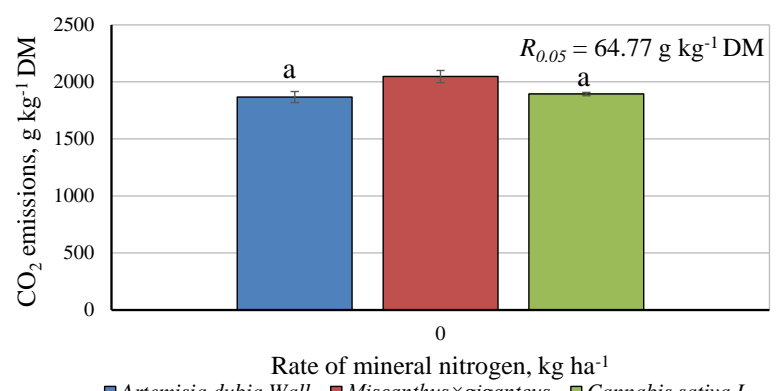

(a)

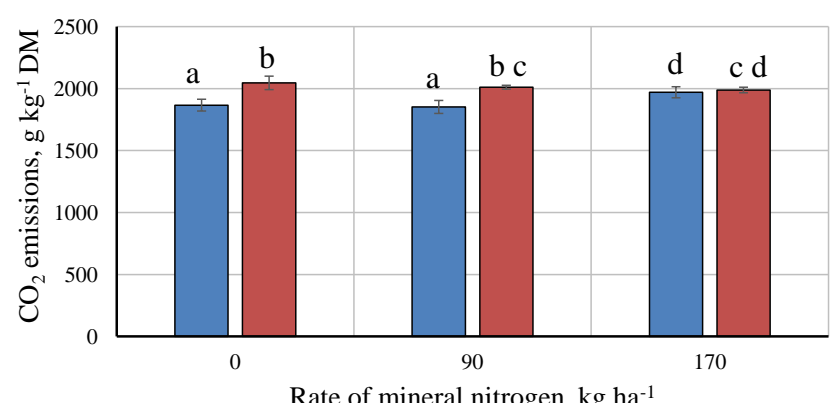

$\square$ Artemisia dubia Wall. $\quad \square$ Miscanthus $\times$ giganteus

(b)

Figure 7. The dependence of $\mathrm{CO}_{2}$ emissions of Artemisia dubia Wall., Miscanthus $\times$ giganteus and Cannabis sativa L. not fertilized (a), on mineral nitrogen fertilization (b) $\left(R_{0.05}(\right.$ A. dubia $)=73.56 \mathrm{~g} \mathrm{~kg}^{-1} \mathrm{DM}, R_{0.05}($ M. giganteus $)=53.09 \mathrm{~g} \mathrm{~kg}^{-1} \mathrm{DM}$, $R_{0.05}($ A. dubia $\times$ M. giganteus $)=50.83 \mathrm{~g} \mathrm{~kg}^{-1} \mathrm{DM}$. a, b, c, d, there are no statistically significant differences $(p<0.05)$ between the columns marked with the same letter, as assessed using the least significant difference.

A significant difference in $\mathrm{CO}_{2}$ emissions compared to the unfertilized variant was detected when fertilizing perennial crop biomass with $170 \mathrm{~kg} \mathrm{ha}^{-1}$ rate of mineral nitrogen. In the case of $M$. giganteus, the average $\mathrm{CO}_{2}$ emissions can be reduced to $57.52 \mathrm{~g} \mathrm{~kg}^{-1} \mathrm{DM}$, while A. dubia increased to $104.52 \mathrm{~g} \mathrm{~kg}^{-1} \mathrm{DM}$.

$\mathrm{CO}$ emissions without fertilization $\left(0.054 \pm 0.008 \mathrm{~g} \mathrm{~kg}^{-1} \mathrm{DM}\right)$ of $A$. dubia were 1.12 times lower than in M. giganteus (Figure 8). However, when the crops were fertilized with 170 and $90 \mathrm{~kg} \mathrm{ha}^{-1}$ rate of mineral nitrogen, a lower amount of $C O$ gas was emitted by M. giganteus; i.e., 1.21 and 1.24 times less than $A$. dubia, respectively. The average $\mathrm{CO}$ gas emission from C. sativa was $0.040 \pm 0.012 \mathrm{~g} \mathrm{~kg}^{-1} \mathrm{DM}$, i.e., 1.35 and 1.51 times lower than in A. dubia and M. giganteus, respectively. The average $\mathrm{CO}$ emissions decrease in the following order:

\section{M. giganteus $>$ A. dubia $>$ C. sativa}

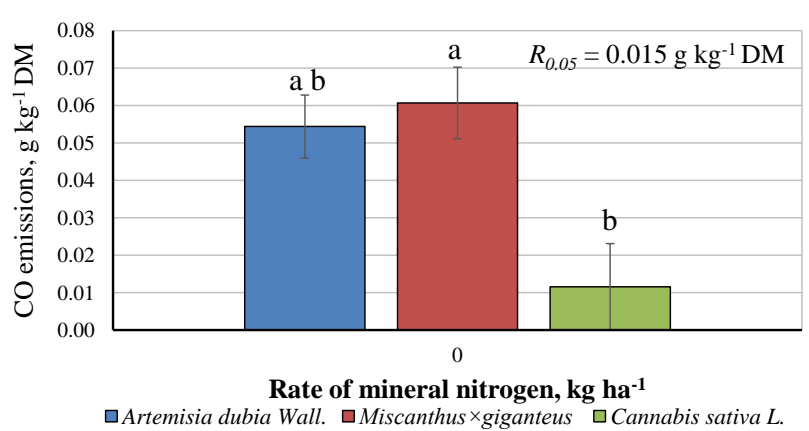

(a)

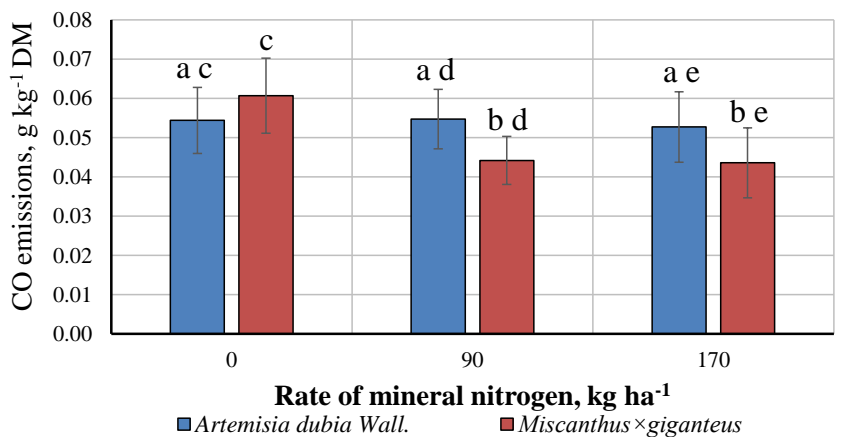

(b)

Figure 8. The dependence of CO emissions of Artemisia dubia Wall., Miscanthus $\times$ giganteus and Cannabis sativa L. not fertilized (a), on mineral nitrogen fertilization (b) $\left(R_{0.05}(\right.$ A. dubia $)=0.013 \mathrm{~g} \mathrm{~kg}^{-1} \mathrm{DM}, R_{0.05}($ M. giganteus $)=0.013 \mathrm{~g} \mathrm{~kg}-1$ $\mathrm{DM}, R_{0.05}($ A. dubia $\times$ M. giganteus $)=0.010 \mathrm{~g} \mathrm{~kg}^{-1} \mathrm{DM} . \mathrm{a}, \mathrm{b}, \mathrm{c}, \mathrm{d}$, e, there are no statistically significant differences $(p<0.05)$ between the columns marked with the same letter, as assessed using the least significant difference.

A significant difference in $\mathrm{CO}$ emissions compared to the unfertilized variant was found when fertilizing M. giganteus biomass with 90 (can be reduced to $0.0165 \mathrm{~g} \mathrm{~kg}^{-1} \mathrm{DM}$ ) and $170 \mathrm{~kg} \mathrm{ha}^{-1}$ (can be reduced to $0.0171 \mathrm{~g} \mathrm{~kg}^{-1} \mathrm{DM}$ ) rate of mineral nitrogen. However, no significant difference was found between fertilization rates. In the case of $A$. dubia, no statistically significant difference was determined between $\mathrm{CO}$ emissions and different fertilization rates. 
M. giganteus was characterized as a crop that emitted less NOx and NO emissions than A. dubia (Figures 9 and 10). M. giganteus emitted 1.51, 1.51 and 1.79 times less than A. dubia, which was fertilized with $90,170 \mathrm{~kg} \mathrm{ha}^{-1}$ and without mineral fertilizers, respectively. However, the amount of $\mathrm{SO}_{2}$ gas emitted during combustion is smaller for $A$. dubia, i.e., $1.01,1.04$ and 1.17 times less than for $M$. giganteus, respectively, without fertilization of the crops and when fertilizing 170 and $90 \mathrm{~kg} \mathrm{ha}^{-1}$. In the case of A. dubia, no statistically significant difference was observed between $\mathrm{NOx}, \mathrm{NO}$ and $\mathrm{SO}_{2}$ emissions and different fertilization rates.

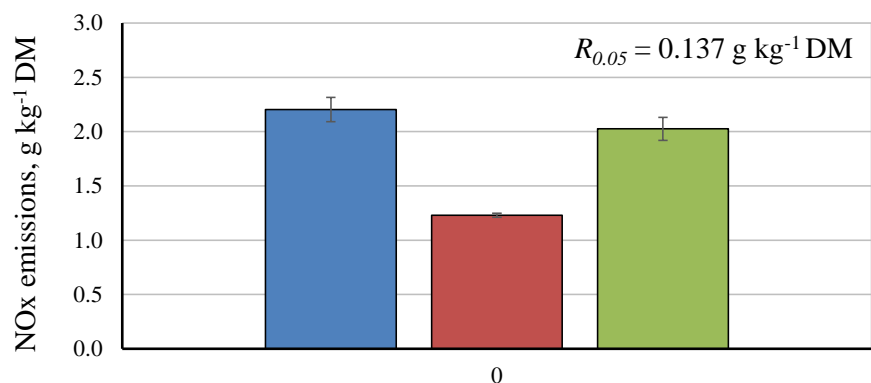

Rate of mineral nitrogen, $\mathrm{kg} \mathrm{ha}^{-1}$ $\square$ Artemisia dubia Wall. $\square$ Miscanthus $\times$ giganteus $\square$ Cannabis sativa $L$

(a)

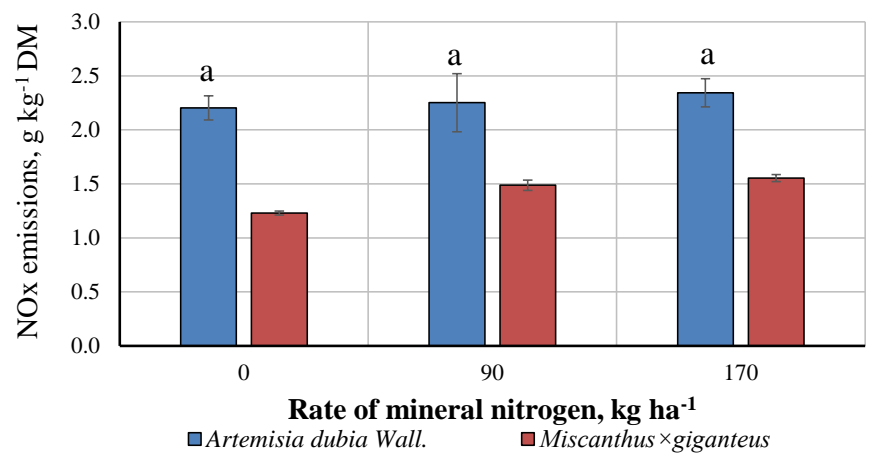

(b)

Figure 9. The dependence of NOx emissions of Artemisia dubia Wall., Miscanthus $\times$ giganteus and Cannabis sativa L. not fertilized (a), on mineral nitrogen fertilization (b) $\left(R_{0.05}(\right.$ A. dubia $)=0.281 \mathrm{~g} \mathrm{~kg}^{-1} \mathrm{DM}, R_{0.05}($ M. giganteus $)=0.053 \mathrm{~g} \mathrm{~kg}^{-1} \mathrm{DM}$, $R_{0.05}($ A. dubia $\times$ M. giganteus $)=0.160 \mathrm{~g} \mathrm{~kg}^{-1} \mathrm{DM}$. a, there are no statistically significant differences $(p<0.05)$ between the columns marked with the same letter, as assessed using the least significant difference.

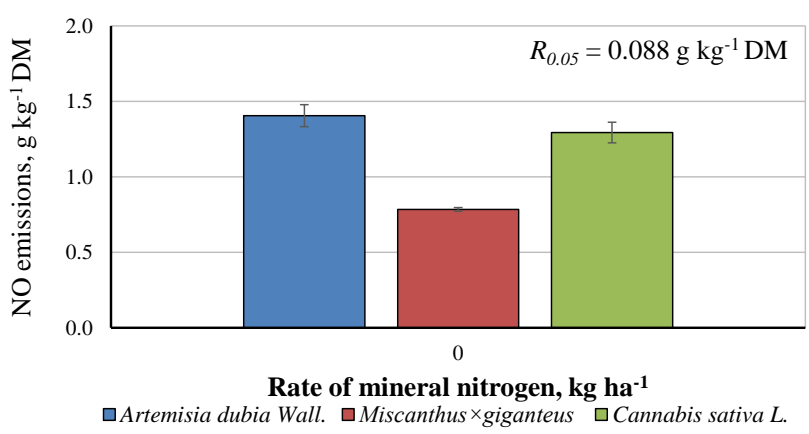

(a)

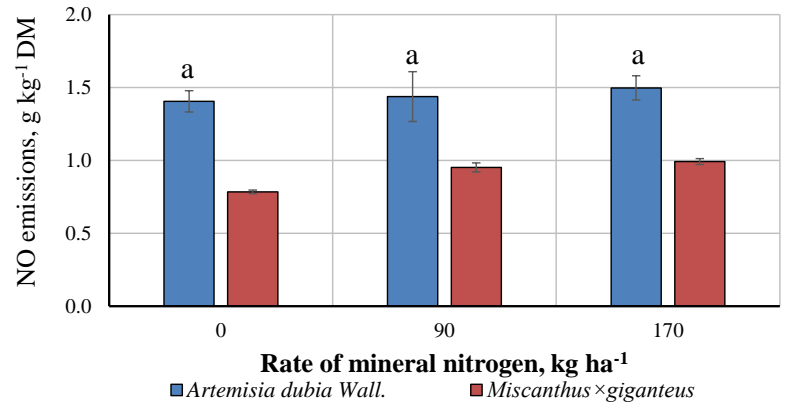

(b)

Figure 10. The dependence of NO emissions of Artemisia dubia Wall., Miscanthus $\times$ giganteus and Cannabis sativa L. not fertilized (a), on mineral nitrogen fertilization (b) $\left(R_{0.05}(\right.$ A. dubia $)=0.179 \mathrm{~g} \mathrm{~kg}^{-1} \mathrm{DM}, R_{0.05}($ M. giganteus $)=0.034 \mathrm{~g} \mathrm{~kg}^{-1} \mathrm{DM}$, $R_{0.05}$ (A. dubia $\times$ M. giganteus $)=0.102 \mathrm{~g} \mathrm{~kg}^{-1} \mathrm{DM}$. a, there are no statistically significant differences $(p<0.05)$ between the columns marked with the same letter, as assessed using the least significant difference.

However, the fertilization of $M$. giganteus with mineral nitrogen increases NOx and NO emissions. Average NOx and NO emissions increase to 0.259 and $0.325 \mathrm{~g} \mathrm{~kg}^{-1} \mathrm{DM}$ (with $90 \mathrm{~kg} \mathrm{ha}^{-1}$ ), to 0.168 and $0.208 \mathrm{~g} \mathrm{~kg}^{-1} \mathrm{DM}$ (with $170 \mathrm{~kg} \mathrm{ha}^{-1}$ ), respectively.

The NOx and NO gas emissions of C. sativa $\left(2.025 \pm 0.107 \mathrm{~g} \mathrm{~kg}^{-1} \mathrm{DM}\right.$ and $1.293 \pm 0.068 \mathrm{~g} \mathrm{~kg}^{-1} \mathrm{DM}$ ) were 1.09 times lower than in A. dubia and 1.65 times higher than in M. giganteus.

The average of NOx and NO emissions decrease in the following order: 
However, the amount of $\mathrm{SO}_{2}\left(0.104 \pm 0.038 \mathrm{~g} \mathrm{~kg}^{-1} \mathrm{DM}\right)$ emitted by C. sativa was smaller than that of perennial crops (Figure 11): 2.34 and 2.35 times smaller than for $A$. dubia and $M$. giganteus, respectively.

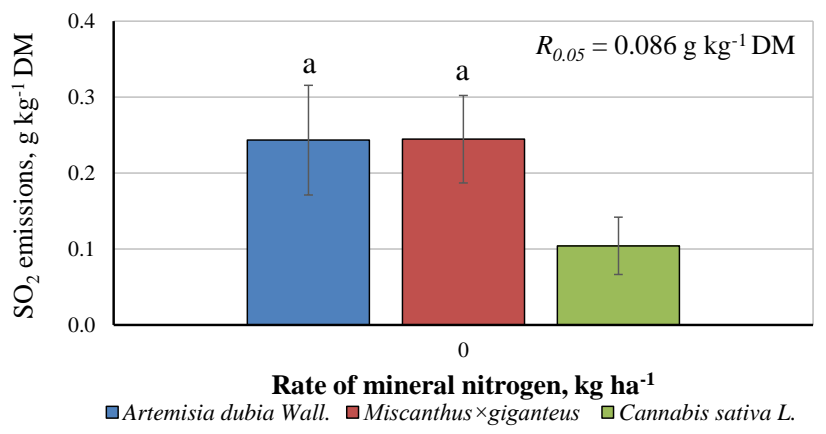

(a)

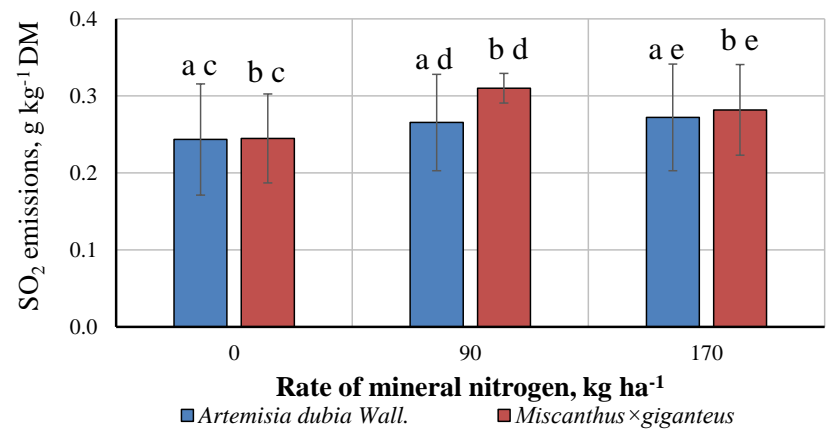

(b)

Figure 11. The dependence of $\mathrm{SO}_{2}$ emissions of Artemisia dubia Wall., Miscanthus $\times$ giganteus and Cannabis sativa L. not fertilized (a), on mineral nitrogen fertilization (b) $\left(R_{0.05}(\right.$ A. dubia $)=0.104 \mathrm{~g} \mathrm{~kg}^{-1} \mathrm{DM}, R_{0.05}($ M. giganteus $)=0.074 \mathrm{~g} \mathrm{~kg}^{-1} \mathrm{DM}$, $R_{0.05}($ A. dubia $\times$ M. giganteus $)=0.071 \mathrm{~g} \mathrm{~kg}^{-1} \mathrm{DM}$. a, there are no statistically significant differences $(p<0.05)$ between the columns marked with the same letter, as assessed using the least significant difference.

The average of $\mathrm{SO}_{2}$ emissions decreases in the following order:

$$
\text { M. giganteus }>\text { A. dubia }>\text { C. sativa }
$$

\section{Discussion}

Calorific value is an important property determining the energy value of biomass. The design of the combustion chamber and the control of this process depend on the calorific values of the biomass fuel to be burned. In the literature, it is indicated that the net calorific value of biomass varies from 15.41 (for beanstalks) to $19.52 \mathrm{MJ} \mathrm{kg}^{-1}$ (for bamboo wood) [22-24]. The experimentally determined calorific value of $A$. dubia biomass varied from $18.50 \pm 0.66$ to $18.78 \pm 0.08 \mathrm{MJ} \mathrm{kg}^{-1}$, while for $M$. giganteus it varied from $18.29 \pm 0.06$ to $18.43 \pm 0.13 \mathrm{MJ} \mathrm{kg}^{-1}$. Lewandowski et al. [25] indicate that the calorific value of $M$. giganteus varies between 17.05 and $19.2 \mathrm{MJ} \mathrm{kg}^{-1}$. Analyzing the fertilization of $A$. dubia and $M$. giganteus biomass with mineral nitrogen, it was observed that the fertilization of biomass with $170 \mathrm{~kg} \mathrm{ha}^{-1}$ can only increase the calorific value to 1.51 (for A. dubia) and $0.74 \%$ (for $M$. giganteus). Fertilization did not have a significant effect on the carbon content of the crops under different fertilization, therefore no significant differences in calorific value were recorded. Moreover, the analysis showed that carbon and its content are the main determinants of the calorific value of the biomass. Meanwhile, the average calorific value of $C$. sativa $\left(17.92 \pm 0.24 \mathrm{MJ} \mathrm{kg}^{-1}\right)$ was 2.08 and $3.66 \%$ lower than that of $M$. giganteus and $A$. dubia, respectively. Researchers highlight that the calorific value of $C$. sativa varies between 15 and $19 \mathrm{MJ} \mathrm{kg}^{-1}[8,26,27]$.

During the analysis of the properties of A. dubia, M. giganteus and C. sativa, the amount of ash formed during combustion was also assessed. The experimentally determined ash content of A. dubia biomass varied from $2.54 \pm 0.50$ to $3.44 \pm 0.39 \%$, and that of $M$. giganteus from $1.51 \pm 0.03$ to $1.65 \pm 0.02 \%$. Lewandowski et al. [25] indicate that the ash content of M. giganteus varies in the range of $1.6-4.02 \%$. Meanwhile, it was monitored that fertilization of A. dubia and M. giganteus biomass with mineral nitrogen did not have a positive effect, and in the case of A. dubia the ash content can be increased up to 1.28 times by applying the maximum fertilization technology. Nitrogen promotes leaf growth and the longevity of green cells. At the same time, the increasing amount of nitrogen fertilizer slows down the woody process of the crops. The ash content increased due to the increased leaf content in the biomass, as leaves have a higher ash content than the woody part of the crop. The higher ash content avoids peaks in combustion changes and makes the combustion process 
more consistent. The average ash content of $C$. sativa $(3.36 \pm 0.23 \%)$ was 1.25 and 2.22 times higher than that of $A$. dubia and $M$. giganteus, respectively. Researchers point out that C. sativa has an ash content of $2.5-4.3 \%[7,8,26]$.

When analyzing the possibility of adapting the studied energy crops to biofuel production, it is crucial to evaluate not only their calorific value and ash content but also the temperatures of their melting characteristics. The melting characteristics of the ash directly affect the operation of the boiler, and the melting of the ash results in slag formation and the formation of impurities that are difficult to remove [10-12,27]. Therefore, it is essential to know the melting characteristics of the ash and control the combustion process. Ash content of herbaceous energy crop biomass can be up to $10 \%[22,23,28,29]$. This is a high ash content compared to the ash content of the wood, which usually does not exceed 1\% [28]. However, the temperatures of their melting characteristics are very close to those of wood. The softening temperature of ash from different types of wood varies from $1180{ }^{\circ} \mathrm{C}$ (pine) to $1477^{\circ} \mathrm{C}$ (birch) [11,30]. The highest ash softening temperature $\left(1468 \pm 55^{\circ} \mathrm{C}\right)$ of the studied crops was recorded when melting $A$. dubia ash, which was 1.49 times higher than for $M$. giganteus. It was monitored that when $M$. giganteus crops were fertilized with mineral nitrogen during cultivation, their DT (up to 1.11 times) and ST (up to 1.19 times) characteristics were determined at higher temperatures. No significant effect of fertilization was recorded for the other $M$. giganteus and all $A$. dubia ash melting characteristics. Meanwhile, the mean onset of initial deformation of $C$. sativa ash was recorded at $648 \pm 8{ }^{\circ} \mathrm{C}$, while values of $A$. dubia and $M$. giganteus ashes for this characteristic were on average 1.1 times and 1.25 times lower, respectively. Poiša and Adamovičs [12,26] indicate that the initial ash deformation can be in the range of $710-1450{ }^{\circ} \mathrm{C}$, depending on the crop variety and fertilization with different amounts of mineral nitrogen. However, the mean softening temperature $\left(1505 \pm 5^{\circ} \mathrm{C}\right)$ of $C$. sativa ash was recorded to be 1.53 times higher than for $M$. giganteus, and for A. dubia within the margin of error.

The environmental impact of $A$. dubia, M. giganteus and $C$. sativa was assessed by studies of their thermal conversion and smoke emissions. The analysis of the chemical composition of crop biomass showed that as the nitrogen fertilization of biomass increased [31], so did the percentage of nitrogen in biomass. This was also reflected in the amount of combustion products produced. It was observed that the smallest amount of carbon dioxide $\left(\mathrm{CO}_{2}\right)\left(1866.44 \pm 47.99 \mathrm{~g} \mathrm{~kg}^{-1} \mathrm{DM}\right)$ during the combustion process without fertilization was formed by burning $1 \mathrm{~kg}$ of $A$. dubia biomass. The $\mathrm{CO}_{2}$ emissions from $A$. dubia biomass were 1.4 and $7.5 \%$ lower than the $\mathrm{CO}_{2}$ emissions from $C$. sativa and $M$. giganteus. The positive effect of mineral nitrogen fertilization was recorded in $M$. giganteus. When its biomass was fertilized with 90 and $170 \mathrm{~kg} \mathrm{ha}^{-1}$, the $\mathrm{CO}_{2}$ content was 1.7 and $2.8 \%$ lower, respectively, compared to the variant without fertilizers. When $A$. dubia biomass was fertilized with $170 \mathrm{~kg} \mathrm{ha}^{-1}$, the amount of $\mathrm{CO}_{2}$ emitted was $5.3 \%$ higher compared to the variant without fertilizers. However, the fertilization with $90 \mathrm{~kg} \mathrm{ha}^{-1}$ did not have a significant impact on $\mathrm{CO}_{2}$ emissions. The increased ash content ensured that the supply air was sufficient for the entire oxidation process. As a result, $\mathrm{CO}_{2}$ levels increased and $\mathrm{CO}$ levels decreased. During the thermal conversion in present boilers, part of the elemental carbon enters the ash or is incompletely burned, meaning that carbon monoxide gas is formed; therefore the actual amount of carbon dioxide in the smoke is lower [32,33]. In addition, the biomass of coarse-energy crops is characterized as not contributing to climate change, as the amount of $\mathrm{CO}_{2}$ consumed during its cultivation is equal to the amount emitted during combustion [34,35].

Although during the experimental studies a higher airflow to the combustion process was supplied, carbon monoxide was not avoided in the smoke. When burning wood,

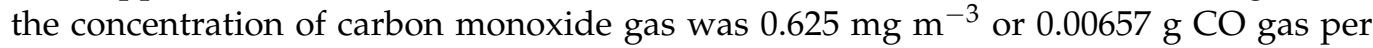
kilogram of wood biomass [32]. When burning the studied coarse-energy crops, higher concentrations of carbon monoxide gas in the smoke were recorded. The lowest content of carbon monoxide (CO) $\left(0.0403 \pm 0.0116 \mathrm{~g} \mathrm{~kg}^{-1} \mathrm{DM}\right)$ during the combustion process without fertilization was generated by burning $1 \mathrm{~kg}$ of $C$. sativa biomass. The $\mathrm{CO}$ emissions 
from C. sativa biomass were 1.35 and 1.51 times smaller than the CO emissions from $A$. dubia and $M$. giganteus. Fertilization of $A$. dubia and M. giganteus biomass with mineral nitrogen had a positive effect on $\mathrm{CO}$ emissions. Fertilization of $A$. dubia reduced the highest amount of $\mathrm{CO}$ by $3.6 \%$, and in the case of $90 \mathrm{~kg} \mathrm{ha}^{-1}$, it varied within the error limits. However, a more significant positive effect was observed for $M$. giganteus. Its fertilization with 90 and $170 \mathrm{~kg} \mathrm{ha}^{-1}$ reduced $\mathrm{CO}$ emissions by 1.37 and 1.39 times, respectively, compared to the variant without fertilization. Carbon monoxide was formed at the beginning of the combustion process, when volatile combustible substances were released. When summarizing the obtained research results, it can be stated that the amount of volatile substances in the studied crops is higher than in wood; therefore, when burning such coarse-energy crops, the control of air and fuel supply must be sufficient $[32,36]$.

The lowest total nitrogen oxide $\left(\mathrm{NO}_{\mathrm{x}}\right)$ content $\left(1.229 \pm 0.0018 \mathrm{~g} \mathrm{~kg}^{-1} \mathrm{DM}\right)$ was released in $M$. giganteus biomass, i.e., 1.65 and 1.79 times lower than in $C$. sativa and A. dubia, respectively. Fertilization of $A$. dubia and $M$. giganteus biomass with mineral nitrogen had a negative effect on their $\mathrm{CO}$ emissions. A. dubia fertilization at 90 and $170 \mathrm{~kg} \mathrm{ha}^{-1}$ increased $\mathrm{NO}_{\mathrm{x}}$ emissions by 2.13 and $5.95 \%$, M. giganteus by 1.21 and 1.26 times, respectively, compared to the unfertilized variant. Krugly et al. [37] indicate that wood emissions were $1.4 \pm 0.2 \mathrm{~g} \mathrm{~kg}^{-1}$, which was not exceeded by coarse-energy crops. The same tendency was observed in nitrous oxide emissions. The increase in NOx and NO contents correlated with the chemical nitrogen content of the biomass, which generally increased with increasing fertilization rates. Researchers report that the amount of gas produced in biomass combustion products is interrelated; when improving the thermochemical conversion process to reduce $\mathrm{CO}_{2}$ and $\mathrm{SO}_{2}, \mathrm{NO}_{x}$ emissions can also be optimized [36,38]. Therefore, improving the management of the incineration process by reducing the flows of combustion products and their impact on the environment is a significant factor.

Biomass is generally low in sulfur and therefore low $\mathrm{SO}_{2}$ emissions during conversion are low [38] compared to other emissions. The lowest amount of sulfur dioxide $\left(0.104 \pm 0.04 \mathrm{~g} \mathrm{~kg}^{-1} \mathrm{DM}\right)$ was released in C. sativa biomass, i.e., 2.34 and 2.35 times less than in A. dubia and M. giganteus, respectively. Fertilization of A. dubia and M. giganteus biomass with mineral nitrogen had a negative effect on the amount of these emissions. A. dubia fertilization at 90 and $170 \mathrm{~kg} \mathrm{ha}^{-1}$ increased $\mathrm{SO}_{2}$ release by 1.09 and 1.12 times, M. giganteus by 1.27 and 1.15 times, respectively, compared to the unfertilized variant. No significant changes in sulfur oxides were observed, nor were there changes in the chemical composition of the biomass with different fertilization.

In conclusion, A. dubia, M. giganteus and C. sativa biomass should be used for thermochemical conversion and their GHG emissions balance close to zero, which was determined in the laboratory.

\section{Conclusions}

The average calorific value of $C$. sativa $\left(17.92 \pm 0.24 \mathrm{MJ} \mathrm{kg}^{-1}\right)$ was recorded to be only $2.08 \%$ and $3.66 \%$ lower than that of M. giganteus and A. dubia, respectively. However, the average ash content of $C$. sativa (3.36 $\pm 0.23 \%)$ was 1.25 and 2.22 times higher than in A. dubia and M. giganteus, respectively.

Analysis of the primary deformation temperature of $A$. dubia, M. giganteus and $C$. sativa revealed that it was the most characteristic for $C$. sativa ash $\left(648 \pm 8^{\circ} \mathrm{C}\right)$, i.e., 1.10 times and 1.25 times lower than for $A$. dubia and $M$. giganteus ash, respectively. However, the mean softening temperature $\left(1505 \pm 5^{\circ} \mathrm{C}\right)$ of $C$. sativa ash was recorded to be 1.53 times higher than for M. giganteus, and for A. dubia within the margin of error.

Significant changes of fertilization were usually $170 \mathrm{~kg} \mathrm{ha}^{-1}$ for $A$. dubia and $90 \mathrm{~kg} \mathrm{ha}^{-1}$ for M. giganteus.

Taking into account the specificity of our research and the changes in biomass ash content due to mineral nitrogen fertilization, it has been found that that higher levels of nitrogen fertilizers in the combustion products reduce $\mathrm{CO}$ and increase the total $\mathrm{CO}_{2}$ content of the combustion product. The increase in NOx and NO contents correlated with 
the chemical nitrogen content of the biomass, which generally increased with increasing fertilization rates. No significant changes in sulfur oxides were observed, nor were there changes in the chemical composition of the biomass with different fertilization.

Altogether, Artemisia dubia Wall., Miscanthus $\times$ giganteus and Cannabis sativa L. biomass should be used for thermochemical conversion, as their GHG emission balance is close to zero, which was determined in the laboratory.

Author Contributions: Conceptualization, methodology, formal analysis and data curation, writingoriginal draft preparation, writing — review and editing, visualization and supervision: Ž.Č., A.J.R., E.Z., V.T. and Z.J. All authors have read and agreed to the published version of the manuscript.

Funding: This research received no external funding.

Conflicts of Interest: The authors declare no conflict of interest.

\section{References}

1. Von Blottnitz, H.; Curran, M.A. A review of assessments conducted on bio-ethanol as a transportation fuel from a net energy, greenhouse gas, and environmental life cycle perspective. J. Clean. Prod. 2007, 15, 607-619. [CrossRef]

2. S Šarūnaitè, L.; Kadžiulienė, Ž.; Tilvikienė, V.; Lazauskas, S. Daugiametės žolès bioenergetikai. In Baltijos Jūros Regiono Bioenergetikos Skatinimo Projekto Leidinys; Akademija: Kèdainiu, Lithuania, 2011; p. 9.

3. Jezierska-Thöle, A.; Rudnicki, R.; Kluba, M. Development of energy crops cultivation for biomass production in Poland. Renew. Sustain. Energy Rev. 2016, 62, 534-545. [CrossRef]

4. Tilvikienè, V.; Kadžiulienè, Ž.; Raila, A.; Zvicevičius, E.; Kadžiulienė, Ž.; Liaudanskienè, I.; Volkavičiūtė, Ž.; Pocienė, L. Artemisia dubia Wall-A novel energy crop for temperate climate zone in Europe. In Proceedings of the 23rd European Biomass Conference and Exhibition, Vienna, Austria, 1-4 June 2015; pp. 147-150. Available online: https://www.researchgate.net/publication/2832 59002 (accessed on 12 December 2020).

5. Jørgensen, U.; Mortensen, J.; Kjeldsen, J.B.; Schwarz, K. Establishment, Development and Yield Quality of Fifteen Miscanthus Genotypes over Three Years in Denmark. Acta Agric. Scand. Sect. B-Soil Plant. Sci. 2003, 53, 190-199.

6. Jankauskienė, Z.; Gruzdevienè, E. Screening of Industrial Hemp (Cannabis sativa L.) Cultivars for Biomass Yielding Capacities in Lithuania. J. Nat. Fibers 2015, 12, 368-377. [CrossRef]

7. Sausserde, R.; Adamovičs, A.; Ivanovs, S.; Bulgakov, V. Investigations into growing and harvesting industrial hemp. J. Res. Appl. Agric. Eng. 2013, 58, 150-154.

8. Komlajeva, L.; Adamovičs, A.; Poiša, L. Comparison of different energy crops for solid fuel production in Latvia. Renew. Energy Energy Effic. 2012, 45-50.

9. Volkavičiutè, Ž.; Raila, A.; Kadžiulienè, Ž.; Zvicevičius, E.; Tilvikiene, V.; Tauras, E. Drying research in perennial mugwort (Artemisia dubia Wall.). In Proceedings of the Engineering for Rural Development: 14th International Scientific Conference, Jelgava, Latvia, 20-22 May 2015; Latvia University of Agriculture: Jelgava, Latvia, 2015; Volume 14, pp. $168-173$.

10. Čepauskienè, D.; Pedišius, N. Mineralogical changes in ash of hemp and wheat straw at different ashing temperatures. In Proceedings of the 16 th International Conference of Young Scientists on Energy Issues, CYSENI 2019, Kaunas, Lithuania, 23-24 May 2019; pp. 1-7.

11. Čepauskienè, D; Pedišius, N. Investigation of the effect of kaolin additive and different ashing temperature of agromass. In Proceedings of the 15th International Conference of Young Scientists on Energy Issues, CYSENI 2018, Kaunas, Lithuania, 23-25 May 2018; pp. 1-35.

12. Poiša, L.; Jankauskienè, Z.; Adamovičs, A.; Gruzdevienè, E.; Platace, R.; Bumane, S. Evaluation of factors influencing ash melting characteristics in linseeds and hemp. In Engineering for Rural Development: 12th International Scientific Conference, Jelgava, Latvia, 23-24 May 2013; Latvia University of Agriculture: Jelgava, Latvia, 2013; Volume 12, pp. 531-535.

13. Jach-Nocó, M.; Pełka, G.; Lubó, W.; Mirowski, T.; Nocó, A.; Pachytel, P. An Assessment of the Efficiency and Emissions of a Pellet Boiler Combusting Multiple Pellet Types. Energies 2021, 14, 4465. [CrossRef]

14. Maj, G.; Najda, A.; Klimek, K.; Balant, S. Estimation of Energy and Emissions Properties of Waste from Various Species of Mint in the Herbal Products Industry. Energies 2020, 13, 55. [CrossRef]

15. Greinert, A.; Mrówczynska, M.; Grech, R.; Szefner, W. The Use of Plant Biomass Pellets for Energy Production by Combustion in Dedicated Furnaces. Energies 2020, 13, 463. [CrossRef]

16. James, A.M.; Yuan, W.; Boyette, M.D. The effect of biomass physical properties on top-lit updraft gasification of woodchips. Energies 2016, 9, 283. [CrossRef]

17. Lee, M.S.; Wycislo, A.; Guo, J.; Lee, D.K.; Voigt, T. Nitrogen Fertilization Effects on Biomass Production and Yield Components of Miscanthus $\times$ giganteus. Front. Plant. Sci. 2017, 8, 544. [CrossRef]

18. Lemus, R.; Charles Brummer, E.; Lee Burras, C.; Moore, K.J.; Barker, M.F.; Molstad, N.E. Effects of nitrogen fertilization on biomass yield and quality in large fields of established switchgrass in southern Iowa, USA. Biomass Bioenergy 2008, 32, $1187-1194$. [CrossRef] 
19. Čepanko, V.; Baltrènas, P. Environmental engineering 50 evaluation of fermented waste energetic characteristics and the numerical modelling of nitrogen oxides concentrations during combustion. In Proceedings of the 8th International Conference “Environmental Engineering", Vilnius, Lithuania, 19-20 May 2011; pp. 50-58. Available online: http://dspace.vgtu.lt/bitstream/ 1/879/1/50_58_Cepanko_others.pdf (accessed on 19 February 2021).

20. Čepanko, V.; Baltrènas, P.; Buinevičius, K. Assessment of air pollution when incinerating fermented waste with combustion gas components. Chem. Process. Eng. 2010, 31, 163-179. Available online: https://www.researchgate.net/publication/287765665 (accessed on 19 February 2021).

21. Prieto, M.M.; Suárez, I.; Fernández, F.J; Sánchez, H.; Mateos, M. Theoretical development of a thermal model for the reheater of a power plant boiler. Appl. Therm. Eng. 2007, 27, 619-626. [CrossRef]

22. Yin, C.-Y. Prediction of higher heating values of biomass from proximate and ultimate analyses. Fuel 2011, 90, 1128-1132. [CrossRef]

23. Erol, M.; Haykiri-Acma, H.; Küçükbayrak, S. Calorific value estimation of biomass from their proximate analyses data. Renew. Energy 2010, 35, 170-173. [CrossRef]

24. Pedišius, N.; Praspaliauskas, M.; Pedišius, J.; Dzenajavičienė, E.F. Analysis of Wood Chip Characteristics for Energy Production in Lithuania. Energies 2021, 14, 3931. [CrossRef]

25. Lewandowski, I.; Clifton-Brown, J.C.; Scurlock, J.M.O.; Huisman, W. Miscanthus: European experience with a novel energy crop. Biomass Bioenergy 2000, 19, 209-227. Available online: https://linkinghub.elsevier.com/retrieve/pii/S0961953400000325 (accessed on 12 December 2020). [CrossRef]

26. Poiša, L.; Adamovičs, A. Evaluate of hemp (Cannabis sativa L.) quality parameters for bioenergy production. Engineering for Rural Development: 10th International Scientific Conference, Jelgava, Latvia, 26-27 May 2011; Latvia Academy of Agricultural and Forestry Sciences Division of Engineering: Jelgava, Latvia, 2011; 10, pp. 358-362.

27. Mankowski, J.; Kolodziej, J.; Baraniecki, P. Industrial hemp grown in remediated land used for energy. Chemik 2014, 10, 901-904.

28. Shen, J.; Zhu, S.; Liu, X.; Zhang, H.; Tan, J. The prediction of elemental composition of biomass based on proximate analysis. Energy Convers. Manag. 2010, 51, 983-987. [CrossRef]

29. Alakangas, E. Properties of Wood Fuels Used in Finland-BIOSOUTH-Project. 2005. Available online: www.bio-south.com (accessed on 12 December 2020).

30. Tilvikienè, V.; Kadžiulienė, Ž.; Liaudanskienė, I.; Zvicevičius, E.; Černiauskienè, Ž.; Čiplienè, A.; Raila, A.J.; Baltrušaitis, J. The quality and energy potential of introduced energy crops in northern part of temperate climate zone. Renew. Energy 2020, 151, 887-895. [CrossRef]

31. González, J.F.; González-García, C.M.; Ramiro, A.; González, J.; Sabio, E.; Gañán, J.; Rodrígueza, M.A. Combustion optimisation of biomass residue pellets for domestic heating with a mural boiler. Biomass Bioenergy 2004, 27, 145-154. [CrossRef]

32. Jetter, J.; Zhao, Y.; Smith, K.R.; Khan, B.; Yelverton, T.; DeCarlo, P.; Hays, M.D. Pollutant Emissions and Energy Efficiency under Controlled Conditions for Household Biomass Cookstoves and Implications for Metrics Useful in Setting International Test Standards. Environ. Sci. Technol. 2012, 46, 10827-10834. [CrossRef]

33. Pandey, V.C.; Bajpai, O.; Singh, N. Energy crops in sustainable phytoremediation. Renew. Sustain. Energy Rev. 2016, 54, 58-73. [CrossRef]

34. Singh, A.; Pant, D.; Korres, N.E.; Nizami, A.S.; Prasad, S.; Murphy, J.D. Key issues in life cycle assessment of ethanol production from lignocellulosic biomass: Challenges and perspectives. Bioresour. Technol. 2010, 101, 5003-5012. [CrossRef] [PubMed]

35. Al-Mansour, F.; Zuwala, J. An evaluation of biomass co-firing in Europe. Biomass Bioenergy 2010, 34, 620-629. [CrossRef]

36. Krugly, E.; Martuzevicius, D.; Puida, E.; Buinevicius, K.; Stasiulaitiene, I.; Radziuniene, I.; Minikauskas, A.; Kliucininkas, L. Characterization of Gaseous- and Particle-Phase Emissions from the Combustion of Biomass-Residue-Derived Fuels in a Small Residential Boiler. Energy Fuels 2014, 28, 5057-5066. [CrossRef]

37. Rokni, E.; Ren, X.; Panahi, A.; Levendis, Y.A. Emissions of $\mathrm{SO}_{2}, \mathrm{NO}_{\mathrm{x}}, \mathrm{CO}_{2}$, and $\mathrm{HCl}$ from Co-firing of coals with raw and torrefied biomass fuels. Fuel 2018, 211 (Suppl. C), 363-374. [CrossRef]

38. Malat'ák, J.; Passian, L. Heat-emission analysis of small combustion equipments for biomass. Res. Agric. Eng. 2011, 57, 37-50. [CrossRef] 